\title{
Neuronal LRP1 Regulates Glucose Metabolism and Insulin Signaling in the Brain
}

\author{
Chia-Chen Liu, ${ }^{1,2}$ Jin Hu, ${ }^{1,2}$ Chih-Wei Tsai, ${ }^{1}$ Mei Yue, ${ }^{1}$ Heather L. Melrose, ${ }^{1}$ Takahisa Kanekiyo, ${ }^{1}$ and Guojun Bu ${ }^{1,2}$ \\ ${ }^{1}$ Department of Neuroscience, Mayo Clinic, Jacksonville, Florida 32224, and ${ }^{2}$ Fujian Provincial Key Laboratory of Neurodegenerative Disease and Aging \\ Research, Institute of Neuroscience, College of Medicine, Xiamen University, Xiamen, Fujian 361005, China
}

\begin{abstract}
Alzheimer's disease $(\mathrm{AD})$ is a neurological disorder characterized by profound memory loss and progressive dementia. Accumulating evidence suggests that Type 2 diabetes mellitus, a metabolic disorder characterized by insulin resistance and glucose intolerance, significantly increases the risk for developing $\mathrm{AD}$. Whereas amyloid- $\beta(\mathrm{A} \beta)$ deposition and neurofibrillary tangles are major histological hallmarks of $\mathrm{AD}$, impairment of cerebral glucose metabolism precedes these pathological changes during the early stage of $\mathrm{AD}$ and likely triggers or exacerbates $\mathrm{AD}$ pathology. However, the mechanisms linking disturbed insulin signaling/glucose metabolism and $\mathrm{AD}$ pathogenesis remain unclear. The low-density lipoprotein receptor-related protein 1 (LRP1), a major apolipoprotein E receptor, plays critical roles in lipoprotein metabolism, synaptic maintenance, and clearance of A $\beta$ in the brain. Here, we demonstrate that LRP1 interacts with the insulin receptor $\beta$ in the brain and regulates insulin signaling and glucose uptake. LRP1 deficiency in neurons leads to impaired insulin signaling as well as reduced levels of glucose transporters GLUT3 and GLUT4. Consequently, glucose uptake is reduced. By using an in vivo microdialysis technique sampling brain glucose concentration in freely moving mice, we further show that LRP1 deficiency in conditional knock-out mice resulted in glucose intolerance in the brain. We also found that hyperglycemia suppresses LRP1 expression, which further exacerbates insulin resistance, glucose intolerance, and AD pathology. As loss of LRP1 expression is seen in AD brains, our study provides novel insights into insulin resistance in $\mathrm{AD}$. Our work also establishes new targets that can be explored for $\mathrm{AD}$ prevention or therapy.
\end{abstract}

Key words: Alzheimer's disease; apolipoprotein E; glucose metabolism; insulin signaling; LRP1

\section{Introduction}

Insulin signaling is best known for regulating glucose homeostasis in peripheral tissues, but evidence also supports its role in brain glucose utilization in specific brain areas, including hippocampus (Park, 2001). Although whether insulin is made in the brain remains controversial, it is clear that insulin can cross the blood-brain barrier (BBB) and is abundantly detected in the brain. Insulin receptor $\beta$ (IR $\beta$ ), along with downstream signaling components, is highly expressed in neurons in different brain regions (Baker et al., 2011; Kleinridders et al., 2014). In addition to regulating cellular glucose uptake, insulin controls diverse biological processes, including lipid metabolism, regulation of appetite, and reproductive function (Kahn et al., 2006; Baker et al.,

Received Dec. 20, 2014; revised Feb. 8, 2015; accepted March 7, 2015.

Author contributions: C.-C.L., J.H., H.L.M., T.K., and G.B. designed research; C.-C.L., J.H., C.-W.T., M.Y., and T.K. performed research; C.-C.L., H.L.M., and G.B. contributed unpublished reagents/analytic tools; C.-C.L., J.H., C.-W.T., M.Y., H.L.M., T.K., and G.B. analyzed data; C.-C.L., T.K., and G.B. wrote the paper.

This work was supported by National Institutes of Health Grants R01AG027924, R01AG035355, R01AG046205, P01AG30128, P01NS074969, and P50AG016574 to G.B., the BrightFocus Foundation, the Alzheimer's Association and Cure Alzheimer's Fund to G.B., Alzheimer's Association New Investigator Grant to T.K., and the Mayo Clinic Alzheimer's Disease Research Center pilot grant to C.-C.L. We thank Dr. Mingjie Li and Nada Husic from the Viral Vectors Core (Washington University) for producing the lentiviruses; and Caroline Stetler for careful reading of the manuscript.

The authors declare no competing financial interests.

Correspondence should be addressed to Dr. Guojun Bu, Department of Neuroscience, Mayo Clinic, 4500 San Pablo Road, Jacksonville, FL 32224. E-mail: bu.guojun@mayo.edu.

DOI:10.1523/JNEUROSCI.5180-14.2015

Copyright $\odot 2015$ the authors $\quad 0270-6474 / 15 / 355851-09 \$ 15.00 / 0$
2011; Kleinridders et al., 2014). Alzheimer's disease (AD) is a progressive neurodegenerative disease and a major cause of dementia in the elderly (Thies and Bleiler, 2013). Although depositions of amyloid- $\beta(\mathrm{A} \beta)$ plaques and neurofibrillary tangles are the major histological hallmarks of $\mathrm{AD}$, the reduction of cerebral glucose metabolism correlates with disease progression and predicts histopathological diagnosis in AD (Minoshima, 2003; Mosconi et al., 2009, 2010; Cohen and Klunk, 2014). The development of $\mathrm{AD}$ and diabetes, two age-related diseases, has been found to share many pathophysiological features, including insulin resistance, impaired glucose metabolism, and cognitive decline (Sims-Robinson et al., 2010). Individuals with diabetes have 1.5- to 2.0-fold higher risk of developing $\mathrm{AD}$ than individuals without diabetes (Biessels et al., 2006). Furthermore, a Phase II clinical trial with insulin nasal spray in AD patients has yielded positive results in preventing cognitive decline and has led to a national plan for a Phase III insulin trail (Craft et al., 2012). Along with the encouraging clinical outcomes, it is imperative to understand the mechanism and regulation of insulin signaling and glucose metabolism in preclinical models.

Several lines of evidence suggest the roles of low-density lipoprotein receptor-related protein 1 (LRP1) in AD pathogenesis (Kanekiyo and $\mathrm{Bu}, 2014$ ). LRP1 is a large endocytic receptor that regulates the metabolism of over 40 ligands, including $A \beta$ and apolipoprotein E (apoE) (Herz and Strickland, 2001; Lillis et al., 2008). Its level has been shown to be significantly decreased in AD 
brains and correlates with ages at onset of disease (Kang et al., 2000). Studies suggest that LRP1 interacts and regulates the functions of several cell surface receptors, and also plays crucial roles in maintaining synaptic integrity and cholesterol homeostasis in the brain (Herz and Strickland, 2001; Lillis et al., 2008; Liu et al., 2010). Interestingly, previous studies in adipocytes and hepatocytes have shown that insulin treatment rapidly increases the level of cell surface LRP1 (Ko et al., 2001; Tamaki et al., 2007). LRP1 is also a major constituent of glucose transporter GLUT4 storage vesicle in adipocytes (Jedrychowski et al., 2010). Disturbances of GLUT functions are also involved in AD pathogenesis (Simpson et al., 1994; Sims-Robinson et al., 2010). We thus investigated whether neuronal LRP1 regulates glucose metabolism and serves as the potential link connecting insulin resistance and $\mathrm{AD}$ pathogenesis using both in vitro and in vivo models.

\section{Materials and Methods}

Animals and tissue preparation. All animal procedures were approved by the Institutional Animal Care and Use Committee at Mayo Clinic and in accordance with the regulations of the American Association for the Accreditation of Laboratory Animal Care. Forebrain neuron-specific Lrp1-KO mice $\left(\mathrm{n} L r p 1^{-/-}\right)$were generated by breeding the Lrp1 floxed mice (Rohlmann et al., 1998) with $\alpha$-calcium-calmodulindependent kinase II ( $\alpha$ CaMKII)-driven Cre recombinase mice (The Jackson Laboratory). Littermates of male $\mathrm{n} L r p 1^{-1-}$ mice $\left(\operatorname{Lrp} 1^{\text {flox/flox }}\right.$,

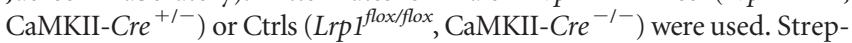
tozotocin (STZ)-injected diabetic mice were purchased from The Jackson Laboratory. Briefly, 8-week-old C57BL/6J males received daily intraperitoneal injection of $50 \mathrm{mg} \mathrm{STZ} / \mathrm{kg}$ body weight for 5 consecutive days; age-matched controls received buffer-only injections. The mice were observed daily until day 16 of the study ( $10 \mathrm{~d}$ after injection). The diabetic mice with nonfasted blood glucose levels of at least 300-400 $\mathrm{mg} / \mathrm{dl}$ were selected for our studies. We then performed in vivo microdialysis to examine the interstitial fluid (ISF) glucose levels in these STZinjected diabetic mice. Blood glucose levels were measured before the microdialysis experiment and before tissue harvest using a glucose monitor (True Track Smart System). Brain tissues were dissected and kept frozen at $-80^{\circ} \mathrm{C}$ until further analysis.

Cell culture. Mouse hypothalamic neuronal GT1-7 cells, human SHSY5Y neuroblastoma cells, and mouse embryonic fibroblasts (MEFs) cells were grown in DMEM containing $10 \% \mathrm{FBS}$ and maintained at $37^{\circ} \mathrm{C}$ in humidified air containing $5 \% \mathrm{CO}_{2}$. Primary mouse cortical neurons were obtained from 16 to $18 \mathrm{~d}$ embryos of wild-type mice as previous described (Liu et al., 2010). Cultures were grown in neurobasal medium supplemented with B27, 0.5 mm glutamine, penicillin, and streptomycin.

Lentivirus-delivered RNA interference. LRP1-specific shRNAs were purchased from Sigma, and lentiviruses were produced in the Viral Vectors Core facility at Washington University School of Medicine. In brief, 293T cells were transfected with pLKO.1-derived constructs together with the pHR8.2 and pCMV-VSV-G packaging systems as previously described (Stewart et al., 2003). Nontarget shRNA was used as a control.

In vivo glucose microdialysis. In vivo microdialysis was used to assess the ISF glucose concentration in the hippocampus of $\mathrm{nrpl}^{-1-}$ mice $\left(\operatorname{Lrp} 1^{\text {flox/flox }}, \mathrm{CaMKII-Cre^{+/- }}\right)$ or Ctrl ( $\left.\operatorname{Lrpl}^{\text {flox/flox }}, \mathrm{CaMKII-Cre^{-/- }}\right)$ mice. Mice were anesthetized with $1 \%-2 \%$ isoflurane, and guide cannulae (CMA Microdialysis or Bioanalytical Systems) were surgically implanted into the hippocampus ( $3.1 \mathrm{~mm}$ behind bregma, $2.5 \mathrm{~mm}$ lateral to midline, and $1.2 \mathrm{~mm}$ below dura at a $12^{\circ}$ angle) using a standard stereotaxic frame (Kopf). Mice were allowed to recover for $24 \mathrm{~h}$. Microdialysis experiments were performed on conscious, freely moving mice. On the day of the experiment, the stylet in the guide cannula was replaced with the microdialysis probe. Probes of $6 \mathrm{kDa}$ molecular weight cutoff membrane (CMA Microdialysis) were used for $\mathrm{nLrp1} 1^{-1-}$ mice and $30 \mathrm{kDa}$ molecular weight cutoff membrane (Bioanalytical Systems) for STZ diabetic mice. The probe was perfused at $2 \mu \mathrm{l} / \mathrm{min}$ with aCSF $(145 \mathrm{~mm} \mathrm{NaCl}$, $1.2 \mathrm{mM} \mathrm{CaCl}_{2}, 3 \mathrm{~mm} \mathrm{KCl}$, and $1.0 \mathrm{~mm} \mathrm{MgCl}_{2}$ ) for a $2 \mathrm{~h}$ equilibration period before sample collection. For brain glucose tolerance test, mice were fasted overnight, and D-glucose at $2 \mathrm{~g} / \mathrm{kg}$ of body weight was injected intraperitoneally after baseline ISF collections. The microdialysis samples were collected every $20 \mathrm{~min}$. The glucose concentration in the ISF samples was measure by Glucose Assay Kit (Abcam).

Cell biotinylation assay. Cells were washed twice with PBS, and surface proteins were labeled with Sulfo-NHS-SS-Biotin (Pierce) under gentle shaking at $4^{\circ} \mathrm{C}$ for $30 \mathrm{~min}$. Quenching solution (Pierce) was added to cells at $4^{\circ} \mathrm{C}$ and washed twice with Tris-buffered saline. Cells were lysed in 500 $\mu \mathrm{l}$ of lysis buffer, incubated for $30 \mathrm{~min}$ on ice. To isolate biotin-labeled proteins, lysate was added to immobilized NeutroAvidin Gel and incubated for $60 \mathrm{~min}$ at room temperature. Gels were washed 5 times with wash buffer and incubated for $60 \mathrm{~min}$ with SDS-PAGE sample buffer, including dithiothreitol. Surface and total proteins were analyzed by Western blot.

Western blot and coimmunoprecipitation. Samples were homogenized and incubated in PBS containing 1\% TX-100, supplemented with protease inhibitor mix, $1 \mathrm{~mm}$ PMSF, and $1 \mathrm{~mm} \mathrm{Na}_{3} \mathrm{VO}_{4}$. Equal amounts of protein (by Bradford assay) were resolved by SDS-PAGE and transferred to PVDF membranes. After the membranes were blocked, proteins were detected with primary antibody. Membrane was probed with LI-COR IRDye secondary antibodies and detected using the Odyssey infrared imaging system (LI-COR). In some experiments, HRP-conjugated secondary antibody was visualized by ECL detection system (Pierce) and exposed to film. For immunoprecipitation, the lysates were precleared using Protein A-agarose beads for $60 \mathrm{~min}$ at $4^{\circ} \mathrm{C}$ and immunoprecipitated overnight at $4^{\circ} \mathrm{C}$ using an in-house anti-LRP1 antibody (Bu et al., 1995) or rabbit IgG as control. The antibody-bound complexes were isolated by incubation with Protein A-agarose beads for $2 \mathrm{~h}$. The precipitates were then washed three times with PBS and resuspended in SDS sample buffer. The following antibodies were used in this study: antiphospho-Ser ${ }^{473}$-Akt (p-Akt), anti-Akt (Cell Signaling Technology), anti-GLUT3, anti-GLUT4 (Milipore), anti-insulin receptor- $\beta$ (Santa Cruz Biotechnology), and anti- $\beta$-actin (Sigma) antibodies.

RNA isolation and real-time PCR analysis. Total RNA was isolated by using Trizol (QIAGEN), RNeasy Mini Kit (QIAGEN), and subjected to DNase I digestion to remove contaminating genomic DNA. Total RNA was dissolved in nuclease-free water and stored at $-80^{\circ} \mathrm{C}$. Reverse transcription was performed using a SuperScript II RNase H-reverse transcriptase (Invitrogen). All primer sets were purchased from SuperArray Biosciences (QIAGEN). The set of actin primers was used as an internal control for each specific gene amplification. The relative levels of expression were quantified and analyzed by using Bio-Rad iCycler iQ. The real-time value for each sample was averaged and compared using the CT method, where the amount of target RNA $\left(2^{-\Delta \Delta C T}\right)$ was normalized to the endogenous actin reference $(\Delta \mathrm{CT})$ and related to the amount of target gene in tissue cells, which was set as the calibrator at 1.0.

Fluorescently labeled glucose uptake assay. Cells were cultured on eightwell slides (Lab-Tek II Chamber Slide System) at $37^{\circ} \mathrm{C}$ for at least $24 \mathrm{~h}$ before experiments. After incubation with fluorescent D-glucose analog 2-[N-(7-nitrobenz-2-oxa-1,3-diazol-4-yl)amino]-2-deoxy-D-glucose (2-NBDG) at $37^{\circ} \mathrm{C}$ for $30 \mathrm{~min}$, fluorescence associated with 2-deoxy-Dglucose was observed by confocal laser-scanning fluorescence microscopy (model LSM 510 invert; Carl Zeiss).

Analysis of BBB integrity. To quantify BBB integrity, the Evans blue dye levels in the brains of mice with or without surgery were assessed. Mice were injected intravenously with $30 \mathrm{mg} / \mathrm{kg}$ Evans blue (Sigma). After $12 \mathrm{~h}$, the brains were extracted after PBS perfusion, which was used to eliminate circulating Evans blue. The tissue was homogenized in $600 \mu \mathrm{l}$ of N,N-dimethyl formamide (Sigma). The homogenate was transferred to new tubes, centrifuged at $14,000 \mathrm{rpm}$ for $20 \mathrm{~min}$ at $4^{\circ} \mathrm{C}$, and the supernatant was plated in triplicate wells in a 96-well flat-bottom plate. For quantification, an Evans blue standard was diluted in the supernatant of a PBS-perfused brain that received no Evans blue but was homogenized in N,N-dimethyl formamide. All samples plated in triplicate were read using a fluorometer ( $620 \mathrm{~nm}$ excitation; $695 \mathrm{~nm}$ emission). The excitation and emission wavelengths were determined by spectral scanning to be optimal for Evans blue. Representative images of Evans blue permeability from $\mathrm{PBS}$ perfused brains were taken using a digital camera. 

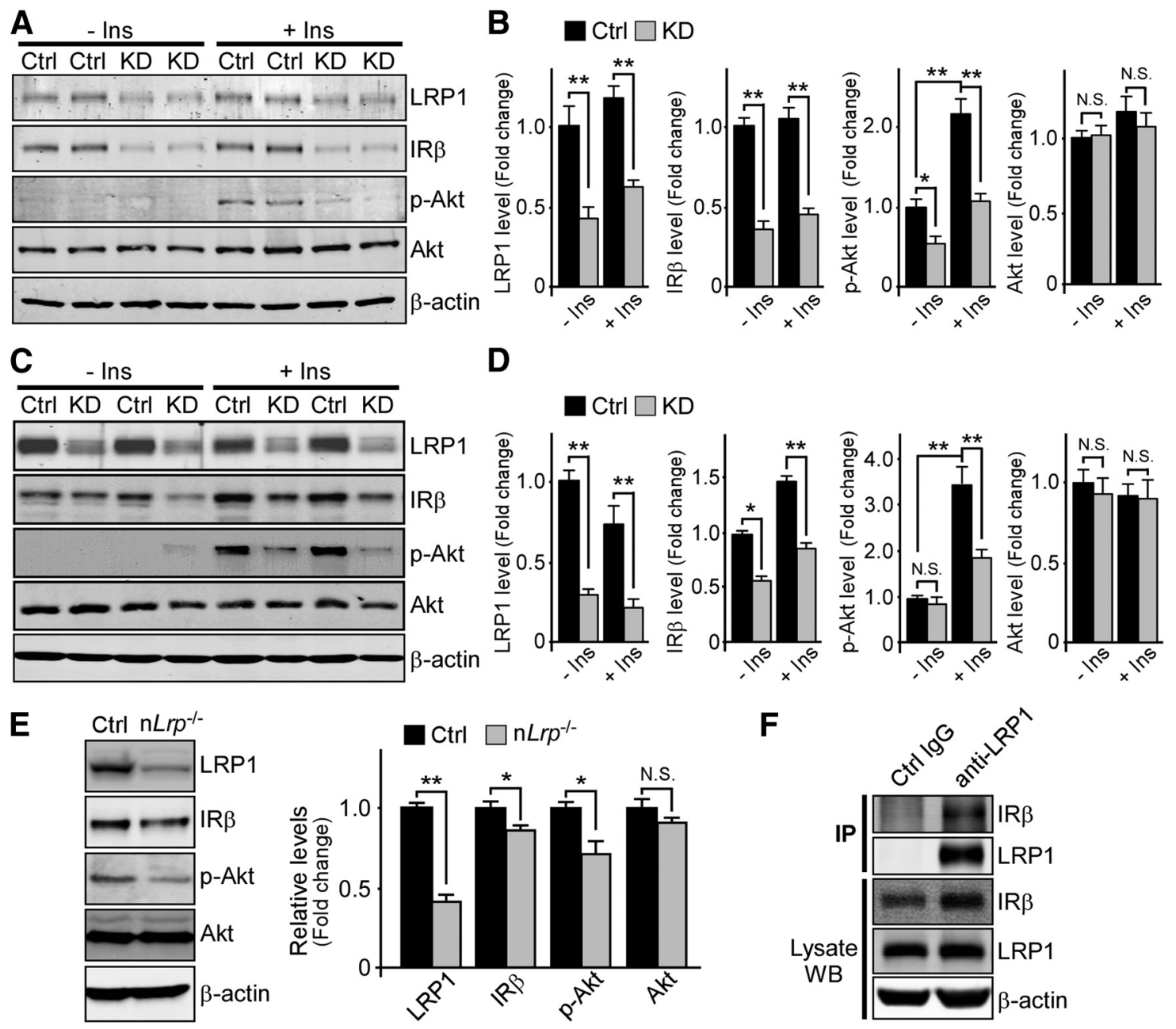

Figure 1. Deficiency of LRP1 in primary neurons and mouse brain leads to decreased insulin receptor levels and signaling. $A, B, G T 1-7$ neuronal cells infected with control or LRP1 shRNA were incubated with serum-free medium for $4 \mathrm{~h}$ and then stimulated with insulin (Ins; $100 \mathrm{~nm}$ ) for 30 min. Lysates from GT1-7 cells were blotted for LRP1, IR $\beta$, total Akt, p-Akt, and $\beta$-actin. C, D, Primary neurons infected with control or LRP1 shRNA were incubated with serum-free medium for $4 \mathrm{~h}$ and then treated with insulin (100 nM) for $30 \mathrm{~min}$. Lysates were blotted for LRP1, IR $\beta$, Akt, $\mathrm{p}$-Akt, and

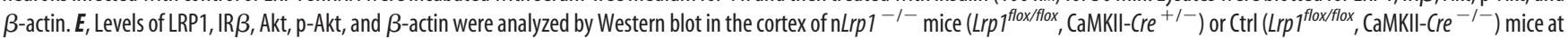
the age of 18 months ( $n=7 /$ group). Data are mean \pm SEM. ${ }^{*} p<0.05 .{ }^{* *} p<0.01$. N.S., Not significant. $F$, Lysates from wild-type mouse brain were immunoprecipitated with either an LRP1 antibody or control rabbit IgG. Immunoprecipitates were then subjected to Western blot analysis with an anti-IR $\beta$ antibody. LRP1 antibody, but not control IgG, immunoprecipitated IR $\beta$.

Statistical analysis. All quantified data represent an average of samples. Statistical significance was determined by two-tailed paired Student's $t$ test, and $p<0.05$ was considered significant.

\section{Results}

Neuronal LRP1 deficiency leads to reduced expression of IR $\beta$ and impaired insulin signaling

To evaluate the impact of LRP1 downregulation on insulin signaling, we established experimental conditions under which LRP1 was efficiently knocked down in GT1-7 cells (immortalized hypothalamic neurons) (Liposits et al., 1991) using lentivirus carrying LRP1 shRNA (Fig. 1A,B). Compared with control shRNA treatment, we found that LRP1 knockdown (KD) significantly reduced IR $\beta$ levels in GT1-7 cells in both the presence and absence of insulin (Fig. $1 A, B$ ). Whereas insulin stimulated phosphorylation of Akt, the levels of phosphorated Akt (p-Akt) were significantly lower in LRP1-KD cells (Fig. $1 A, B$ ). To further examine the roles of LRP1 in insulin signaling, primary cultures of mouse neurons were used. Consistent with results from GT1-7 cells, LRP1 knockdown significantly suppressed the levels of IR $\beta$ regardless of insulin treatment and decreased p-Akt level after insulin stimulation (Fig. 1C,D). These results indicate that LRP1 deficiency disturbs insulin signaling by decreasing IR $\beta$ levels in neurons.

Conditional knock-out of $\operatorname{Lrp} 1$ in forebrain neurons leads to impaired brain insulin signaling

We have previously generated forebrain neuron-specific LRP1 knock-out (nLrp1 $1^{-1-}$ ) mice (Liu et al., 2007) by breeding the $\operatorname{Lrp1}^{\text {flox/flox }}$ mice with $\alpha$ CaMKII-Cre mice (Tsien et al., 1996). To investigate whether neuronal LRP1 deficiency affects insulin signaling in vivo, we compared the levels of IR $\beta$ and insulin signaling in the cortex of $\mathrm{nLrp1} 1^{-1-}$ mice and their littermate controls. Although LRP1 was abundantly expressed in neurons and, to a lesser extent, in glial cells in control mice in cortex (Liu et al., 2007; Kanekiyo et al., 2013), LRP1 levels in the cortex of $\mathrm{n} L r p 1^{-1-}$ mice were significantly decreased at 18 months of age when analyzed by Western blotting (Fig. $1 E$ ). The residual LRP1 observed at older ages likely represents the expression within glial cells and/or brain vasculature (Liu et al., 2007). More important, the levels of IR $\beta$ and p-Akt were significantly decreased in $\mathrm{n} L r p 1^{-1-}$ mice compared with control mice, consistent with our in vitro findings (Fig. $1 E$ ). These results indicate that neuronal 
A

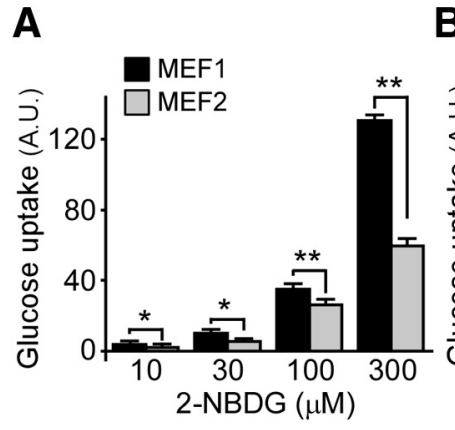

D

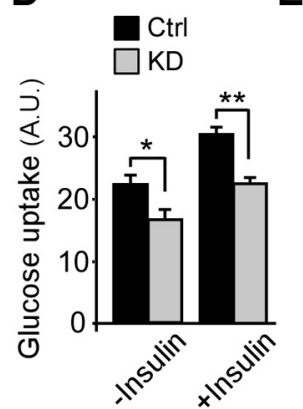

B

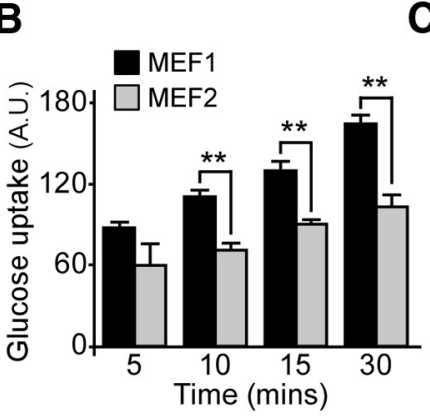

C

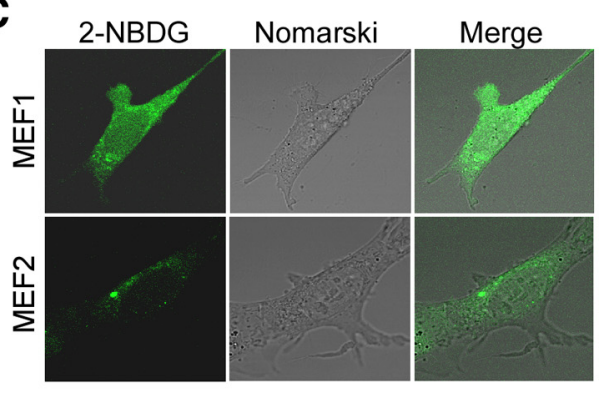

E

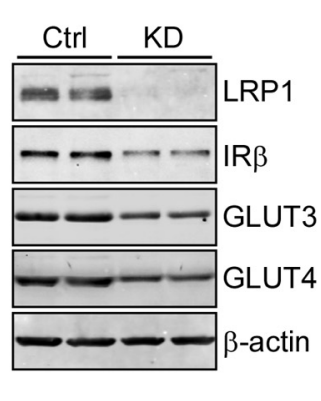

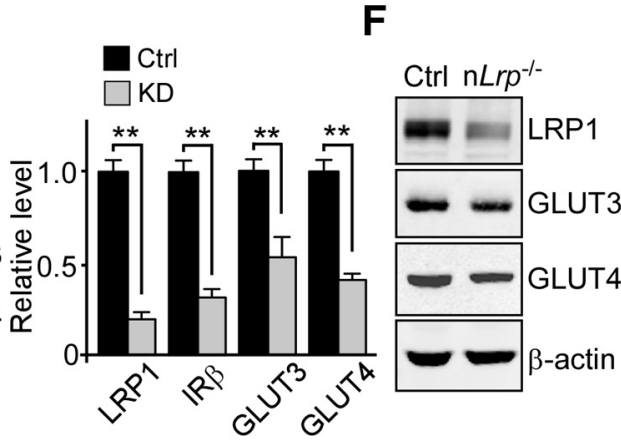

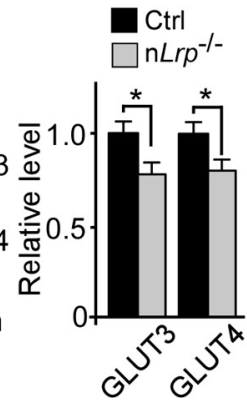

Figure 2. Downregulation of LRP1 leads to a reduction of glucose uptake. $\boldsymbol{A}$, MEF1 (wild-type) and MEF2 (LRP1-deficient) cells were incubated with indicated concentrations of fluorescent 2-NBDG for 20 min at $37^{\circ} \mathrm{C}$. The intracellular fluorescence of 2-NBDG was detected by flow cytometry. $\boldsymbol{B}$, MEF1 (wild-type) and MEF2 (LRP1-deficient) cells were incubated with 2-NBDG (300 $\mu$ M) for indicated amounts of time at $37^{\circ} \mathrm{C}$. The intracellular fluorescence of 2-NBDG was detected by flow cytometry. C, MEF1 (wild-type) and MEF2 (LRP1-deficient) cells were incubated with 2-NBDG (300 $\mu \mathrm{M})$ for $20 \mathrm{~min}$ at $37^{\circ} \mathrm{C}$. The intracellular fluorescence of 2-NBDG was examined by confocal microscopy. $D, G T 1-7$ neuronal cells infected with control or LRP1 shRNA were incubated with serum-free medium for $4 \mathrm{~h}$ and stimulated with insulin (100 nm) for $20 \mathrm{~min}$. Cells were then treated with 2-NBDG (300 $\mu \mathrm{m})$ in the presence or absence of insulin for 20 min. The intracellular fluorescence was detected by flow cytometry. $E$, Levels of LRP1, IR $\beta$, GLUT3, GLUT4, and $\beta$-actin in primary neurons expressing control or LRP1 shRNA were analyzed by Western blot and quantified. Data are mean \pm SEM. ${ }^{*} p<0.05 .{ }^{* *} p<0.01$. F, Levels of GLUT3, GLUT4, and $\beta$-actin were analyzed by Western blot in the cortex of $\mathrm{nLrp1}{ }^{-/-}$mice $\left(\mathrm{Lrp} 1^{\text {flox/flox }}\right.$, CaMKII-Cre $\left.{ }^{+/-}\right)$or Ctrl (Lrp1 ${ }^{\text {flox/flox }}$, CaMKII-(re ${ }^{-1-}$ ) mice at the age of 18 months ( $n=7-9 /$ group). Data are mean \pm SEM. ${ }^{*} p<0.05$.

LRP1 plays an important role in regulating insulin signaling in the brain. To explore potential mechanisms through which LRP1 regulates IR $\beta$ levels, we examined whether LRP1 interacts with IR $\beta$ using coimmunoprecipitation assays. We found that an LRP1-specific antibody, but not a control IgG antibody, coimmunoprecipitated IR $\beta$ (Fig. $1 F$ ), indicating that LRP1 forms a complex with IR $\beta$ in neurons to regulate insulin signaling.

\section{LRP1 downregulation impairs cellular glucose uptake}

To investigate whether LRP1 downregulation affects glucose metabolism, we performed glucose uptake assays in MEF1 (wildtype) and MEF2 (LRP1-deficient) cells by using a fluorescent 2-NBDG as a tracer (Yamada et al., 2007). Because 2-NBDG uptake is mediated through GLUTs (Yamada et al., 2000), 2-NBDG uptake has been used for monitoring glucose uptake into astrocytes and neurons (Porras et al., 2004; Blomstrand and Giaume, 2006). We found that MEF cells took up 2-NBDG in a concentration- and time-dependent manner, where LRP1 deficiency leads to impaired 2-NBDG uptake when analyzed by FACS (Fig. 2A,B). Confocal microscopy also confirmed the decreased 2-NBDG uptake in MEF2 cells compared with MEF1 cells (Fig. $2 C)$. Whereas insulin treatment facilitated 2-NBDG uptake in GT1-7 cells, LRP1 knockdown significantly suppressed it in both the presence and absence of insulin (Fig. 2D). These results indicate that LRP1 regulates cellular glucose uptake in both insulindependent and -independent manners. Whereas GLUT3 is a major neuronal glucose transporter, the insulin-sensitive GLUT4 is also expressed in neuronal processes and cell bodies (McEwen and Reagan, 2004). Thus, we examined whether LRP1 regulates GLUT3 and GLUT4 expression in mouse primary neurons. We found that the levels of GLUT3 and GLUT4 were also significantly downregulated in LRP1-KD neurons compared with controls (Fig. 2E). When we examined the levels of glucose transporters in the cortex of $\mathrm{nLrp1} 1^{-/-}$mice, GLUT3 and GLUT4 levels were also significantly decreased in $\mathrm{nLrp1} 1^{-1-}$ mice compared with control mice at 18 months of age (Fig. $2 F$ ). These results indicate that LRP1 regulates neuronal glucose homeostasis by modulating GLUT3 and GLUT4 levels as well as insulin signaling in the brain.

\section{LRP1 deficiency in neurons leads to glucose intolerance in the brain}

Given that LRP1 downregulation led to a reduction in glucose uptake in vitro, we next investigated whether LRP1 deficiency affects glucose homeostasis in mouse brains. To directly evaluate glucose metabolism in brain parenchyma of awake mice, we established in vivo microdialysis techniques to measure glucose concentration in the ISF. We found that the fasting ISF glucose levels were significantly higher in $\mathrm{n} L r p 1^{-1-}$ mice compared with their littermate controls (Fig. $3 A$ ). We then performed the glucose tolerance test in which mice were intraperitoneally injected with D-glucose (2 $\mathrm{g} / \mathrm{kg}$ body weight), and the changes of ISF glucose levels in control and $\mathrm{nLrp1} 1^{-/-}$mice were monitored over time. The levels of glucose in the ISF of control and $\mathrm{nLrp1} 1^{-1-}$ mice were significantly increased upon glucose challenge, peaking at $40 \mathrm{~min}$ after challenge, and decreased to baseline levels in a time-dependent manner (Fig. 3B). Importantly, we found that $\mathrm{nLrp1} 1^{-1-}$ mice exhibit a much slower rate of glucose metabolism in the brain compared with control mice (Fig. $3 B$ ). These results indicate that deficiency of LRP1 in neurons significantly sup- 
A

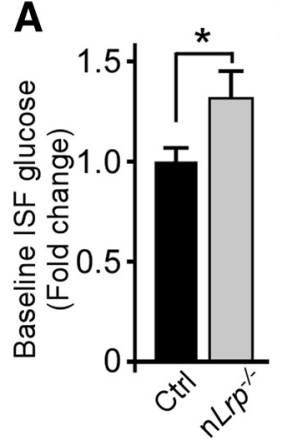

B

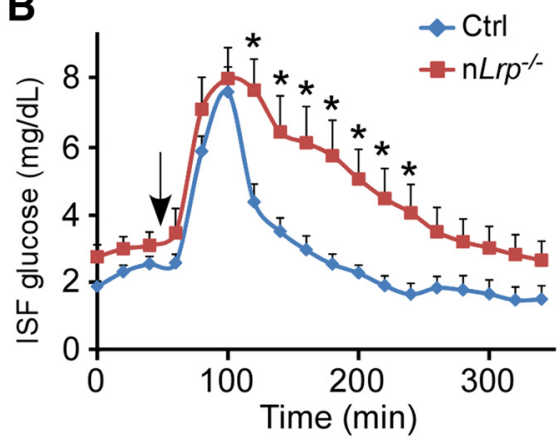

C
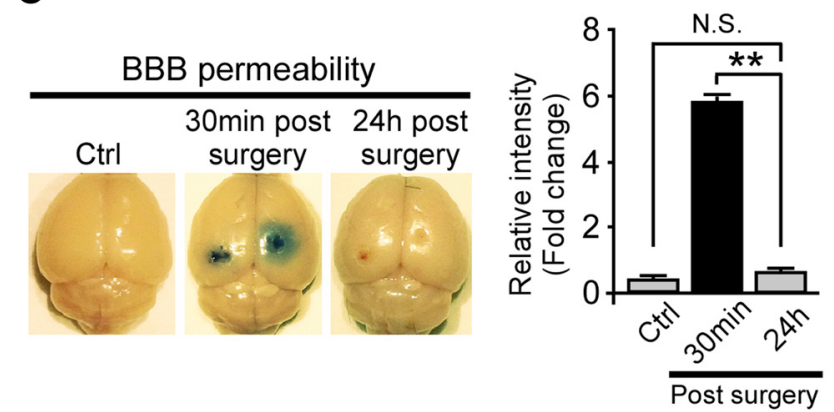

Figure 3. Neuronal deletion of LRP1 results in glucose intolerance in mouse brain. $\boldsymbol{A}, \boldsymbol{B}$, Brain glucose tolerance test was performed on $\mathrm{nLrp1} 1^{-1-}$ mice $\left(\operatorname{Lrp} 1^{\text {flox/flox }}, \mathrm{CaMKII-Cre}{ }^{+/-}\right)$or Ctrl $\left(\mathrm{Lrp} 1^{\text {flox/flox }}, \mathrm{CaMKII}-\mathrm{Cre}{ }^{-/-}\right)$mice at 20-22 months of age. Mice were fasted overnight, and D-glucose at $2 \mathrm{~g} / \mathrm{kg}$ of body weight was injected intraperitoneally as indicated by the arrow after baseline ISF collection. In vivo microdialysis was used to assess the ISF glucose concentration in the hippocampus of free moving mice. The baseline ISF glucose level is higher in $\mathrm{n} L \mathrm{rp} 1^{-1-}$ mice compared with control mice $(\boldsymbol{A})$. $\boldsymbol{B}$, The brain glucose level in each fraction measure by glucose assay was plotted against time. $\mathrm{nLrp} 1^{-1-}$ mice had significantly decreased tolerance in the brain in response to exogenous glucose. Data are mean \pm SEM. $n=7 /$ each group. ${ }^{*} p<$ 0.05 . C, Evans blue dye ( $30 \mathrm{mg} / \mathrm{kg}$ ) was injected intravenously in mice without surgery, $30 \mathrm{~min}$ or $24 \mathrm{~h}$ after surgery. After $12 \mathrm{~h}$, mice were perfused with saline and brains were collected. Representative images of PBS-perfused brains were shown. The Evans blue was extracted using $\mathrm{N}, \mathrm{N}$-dimethyl formamide and quantified using a fluorometer ( $620 \mathrm{~nm}$ excitation; $695 \mathrm{~nm}$ emission). Data are mean \pm SEM. $n=3$ /each group. ${ }^{* *} p<0.01$. N.S., Not significant.

pressed the glucose metabolism in ISF, likely due to impaired insulin signaling and decreased GLUT levels in $\mathrm{nLp1}^{-1-}$ mice. To determine whether implantation of microdialysis probe affects BBB permeability, the animals were intravenously injected with Evans blue dye, and the brains were harvested at $30 \mathrm{~min}$ and $24 \mathrm{~h}$ after surgery. BBB permeability was assessed by quantifying Evans blue dye extravasations. At $30 \mathrm{~min}$ after surgery, we observed a significant leakage of Evans blue dye in the brains of mice implanted with probe (Fig. 3C). However, at $24 \mathrm{~h}$ after surgery, the levels of Evans blue dye in the brains of mice that received probe implantation were similar to those that did not receive surgery (Fig. 3C). This observation suggests that the temporary $\mathrm{BBB}$ leakage resulting from probe implantation was recovered $24 \mathrm{~h}$ after surgery, confirming that the ISF glucose levels we measured were unlikely affected by the blood glucose during microdialysis sampling.

\section{Insulin increases the cell surface presentation of LRP1 in neurons}

Insulin has been shown to increase cell surface localization of LRP1 in adipocytes and hepatocytes (Ko et al., 2001; Tamaki et al., 2007). To investigate how insulin regulates LRP1 distribution in neuronal cells, we performed cell surface biotinylation analysis in SH-SY5Y human neuronal cells in the presence or absence of insulin treatment. Insulin administration stimulated insulin signaling activation, which is shown by an increase in the ratio of p-Akt/total Akt, although it did not affect the levels of total LRP1, GLUT4, and IR $\beta$ (Fig. $4 A, B$ ). As expected, we found that GLUT4 translocated from the intracellular pools to the plasma membrane upon insulin stimulation (Fig. $4 A, C$ ). Importantly, insulin treatment significantly increased cell surface presentation of LRP1 in SH-SY5Y cells as measured by cell surface biotinylation assays (Fig. $4 A, C$ ). As controls, we did not observe significant changes in the cell surface levels of IR $\beta$ and a membrane marker $\mathrm{Na}^{+} / \mathrm{K}^{+}$ATPase (Fig. $4 A, C$ ), indicating that insulin specifically influences the cellular distribution of GLUT4 as well as LRP1. Our results indicate that abnormal levels of insulin in pathological condition, such as diabetes, may contribute to LRP1 dysfunctions, which may further compromise insulin signaling.

\section{Hyperglycemia and insulin deficiency downregulate LRP1 expression in the brain}

To investigate whether LRP1 expression was modulated by glucose levels, SH-SY5Y cells were treated with medium containing various concentrations of glucose, and the levels of LRP1 were examined by Western blot analysis. We found that higher glucose levels (110 mM) significantly suppressed LRP1 expression in SHSY5Y neuronal cells compared with those in normal growth medium containing $25 \mathrm{~mm}$ glucose (Fig. $5 A$ ), suggesting that LRP1 expression is modulated by glucose concentration in neurons. To examine whether insulin deficiency has an effect on LRP1 level, neuronal GT1-7 cells were incubated in serum-free growth medium with or without insulin treatment. Interestingly, we found that LRP1 level was significantly downregulated in the absence of insulin (Fig. 5B). To further investigate whether brain glucose levels affect LRP1 expression in vivo, we used STZ-induced diabetic mice that have been shown to exhibit hyperglycemia and impaired glucose tolerance (Ardestani et al., 2014). We performed glucose tolerance tests in STZ-treated and control mice and monitored their brain glucose levels in ISF using in vivo microdialysis. We found that STZ-induced diabetic mice exhibited higher levels of fasting ISF glucose and also glucose intolerance in the brain upon glucose challenge (Fig. $5 C$ ), similar to what has been observed in the periphery (Zhou et al., 2008). The slope of the natural logarithm of glucose tolerance test curves quantifies the rate of glucose clearance, which was slower in the STZ-injected group ( $p \leq 0.01$; Fig. $5 D$ ). As expected, we also confirmed that STZ-treated mice exhibit significantly higher blood glucose levels (Fig. 5E). In addition, we found that LRP1 levels were significantly downregulated in both the cortex and hippocampus of STZ-treated mouse brains compared with control brains when examined by Western blot (Fig. $5 F$ ), suggesting that hyperglycemia and/or insulin-deficient conditions suppress LRP1 expression in the brain.

\section{Discussion}

Given the strong correlation between insulin signaling, glucose metabolism, and $\mathrm{AD}$ pathogenesis, $\mathrm{AD}$ has been proposed as "Type 3" diabetes (Steen et al., 2005; de la Monte and Wands, 2008). Epidemiological studies have shown that diabetes accelerates the risk of developing AD (Biessels et al., 2006; SimsRobinson et al., 2010). Among AD patients enrolled in the Mayo Clinic Alzheimer Disease Patient Registry, 35\% and 46\% of them exhibit Type 2 diabetes (fasting plasma glucose concentration $>126 \mathrm{mg} / \mathrm{dl}$ ) and impaired glucose tolerance (fasting plasma glucose concentration $110-125 \mathrm{mg} / \mathrm{dl}$ ), respectively (Janson et al., 2004). As such, understanding the biological mechanisms that 
A

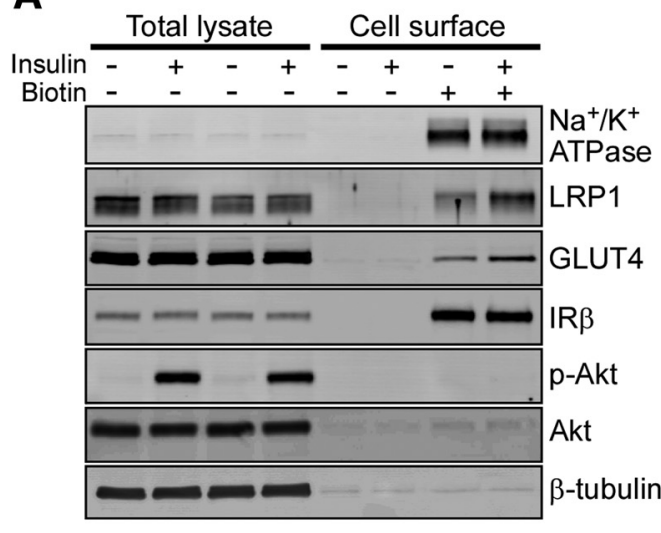

B -insulin $\square+$ insulin

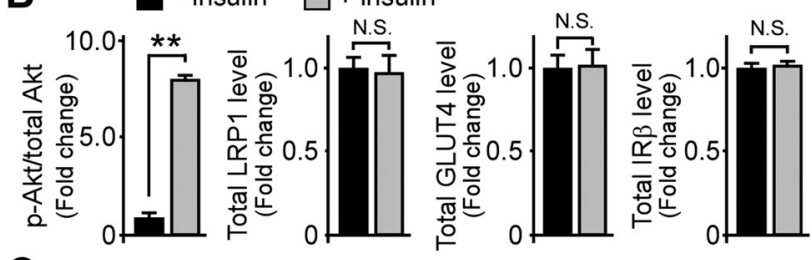

C $\quad$-insulin $\square+$ insulin

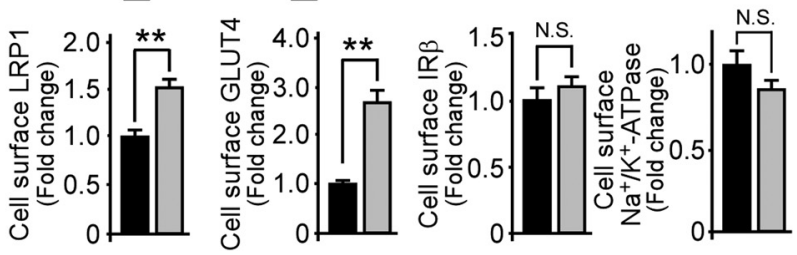

Figure 4. Insulin induces cell surface presentation of LRP1 in neuronal cells. A-C, SH-SY5Y human neuronal cells were treated with or without insulin (100 nm) for $20 \mathrm{~min}$, and the surface proteins were examined by cell surface biotinylation assay. The levels of total and cell surface LRP1, GLUT4, IR $\beta$, and $\beta$-tubulin in SH-SY5Y cells treated with or without insulin were examined by Western blot analysis $(\boldsymbol{A})$ and quantified $\left(\boldsymbol{B}, \boldsymbol{C}\right.$. Induction of $p$-Akt expression confirmed an increase in insulin signaling upon insulin treatment. Data are mean \pm SEM. N.S., Not significant. ${ }^{* *} p<0.01$.
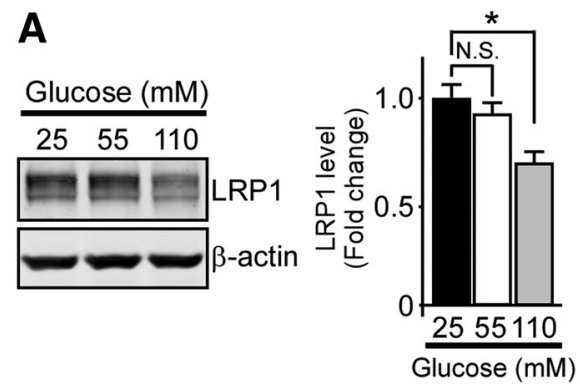

E

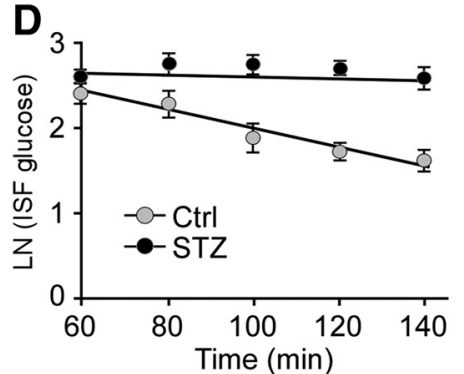

B

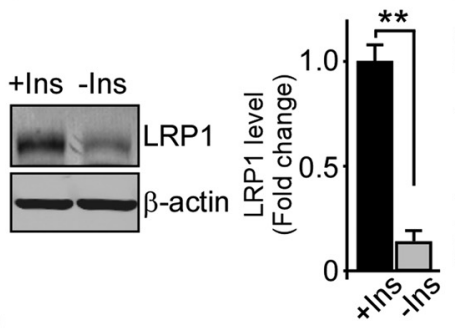

$\mathbf{F}$

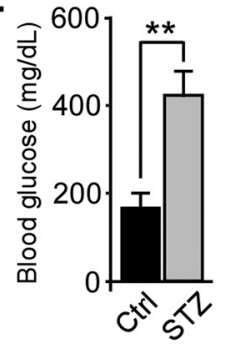

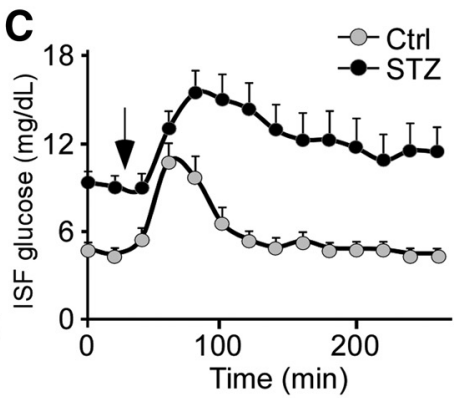

Ctrl $\square$ STZ

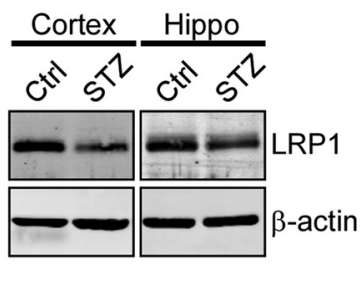

Figure 5. Hyperglycemia and insulin deficiency suppress LRP1 expression in the brain. $A, S H-S Y 5 Y$ cells were treated with low glucose DMEM supplemented with various concentrations of glucose for $48 \mathrm{~h}$. The levels of LRP1 and $\beta$-actin in SH-SY5Y cells were examined by Western blot analysis. The LRP1 level in SH-SH5Y cells treated with regular growth medium DMEM/glucose ( $25 \mathrm{mm)}$ was set as 1.0. Data are mean \pm SEM. ${ }^{*} p<0.05$. B, Neuronal GT1-7 cells cultured in serum-free DMEM growth medium were treated with (+ Ins, $100 \mathrm{~nm}$ ) or without insulin ( - Ins) for $24 \mathrm{~h}$. The levels of LRP 1 and $\beta$-actin were examined by Western blot analysis. C, D, Brain glucose tolerance test was performed on STZ-injected diabetic mice and control mice at 3 months of age. Mice were fasted overnight, and D-glucose at $2 \mathrm{~g} / \mathrm{kg}$ of body weight was injected intraperitoneally as indicated by the arrow after baseline ISF collection. In vivo microdialysis was used to assess ISF glucose levels in the hippocampus of freely moving mice. The brain glucose level in each fraction measure by glucose assay was plotted against time $(\boldsymbol{C})$. The rate of glucose clearance was shown as a function of the slope of the natural log of glucose levels against time (D). Data are mean \pm SEM. $n=4 /$ each group. ${ }^{* *} p<0.01$. N.S., Not significant. E, Blood glucose in STZ-injected diabetic mice and control mice was measured by glucose monitor. $\boldsymbol{F}$, The levels of LRP1 in the cortex and hippocampus of STZ-injected diabetic mice and control mice were examined by Western blot analysis and quantified. Data are mean \pm SEM. $n=4$ /each group. ${ }^{*} p<0.05$.

link the development of diabetes with $\mathrm{AD}$ is essential for the development of future $\mathrm{AD}$ drug intervention and/or prevention strategies.

Glucose is the main energy source for neurons; thus, neuronal glucose homeostasis is precisely controlled through GLUTs in an insulin-dependent and -independent manner (McEwen and Reagan, 2004). Importantly, decreased cerebral glucose metabolism is an early event in $\mathrm{AD}$ pathogenesis and may play a central role in the manifestation of the neuropathological changes associated with AD. Such events can be detected in patients with mild cognitive impairment (MCI) who subsequently develop AD, up to 20 years before the first symptoms of the disease (Mosconi et al., 2010). Furthermore, mounting evidence shows that insulin resistance and/or insulin insufficiency, which cause impaired cerebral glucose utilization, increase the risk of cognitive deficits as well as AD (Stolk et al., 1997; Brands et al., 2005; Biessels et al., 2006; Sims-Robinson et al., 2010; Talbot et al., 2012). Brain levels of insulin and $\operatorname{IR} \beta$ are lower in $\mathrm{AD}$, and impaired insulin signaling has been documented in both postmortem cases and in animal models of AD (Hoyer, 2004; Steen et al., 2005). Insulin signaling also plays important roles in synaptic plasticity, learning, and memory (Skeberdis et al., 2001; Gerozissis, 2003). IR $\beta$ expression is upregulated in the rat hippocampus during spatial memory tasks (Zhao et al., 1999), implying a close relationship 


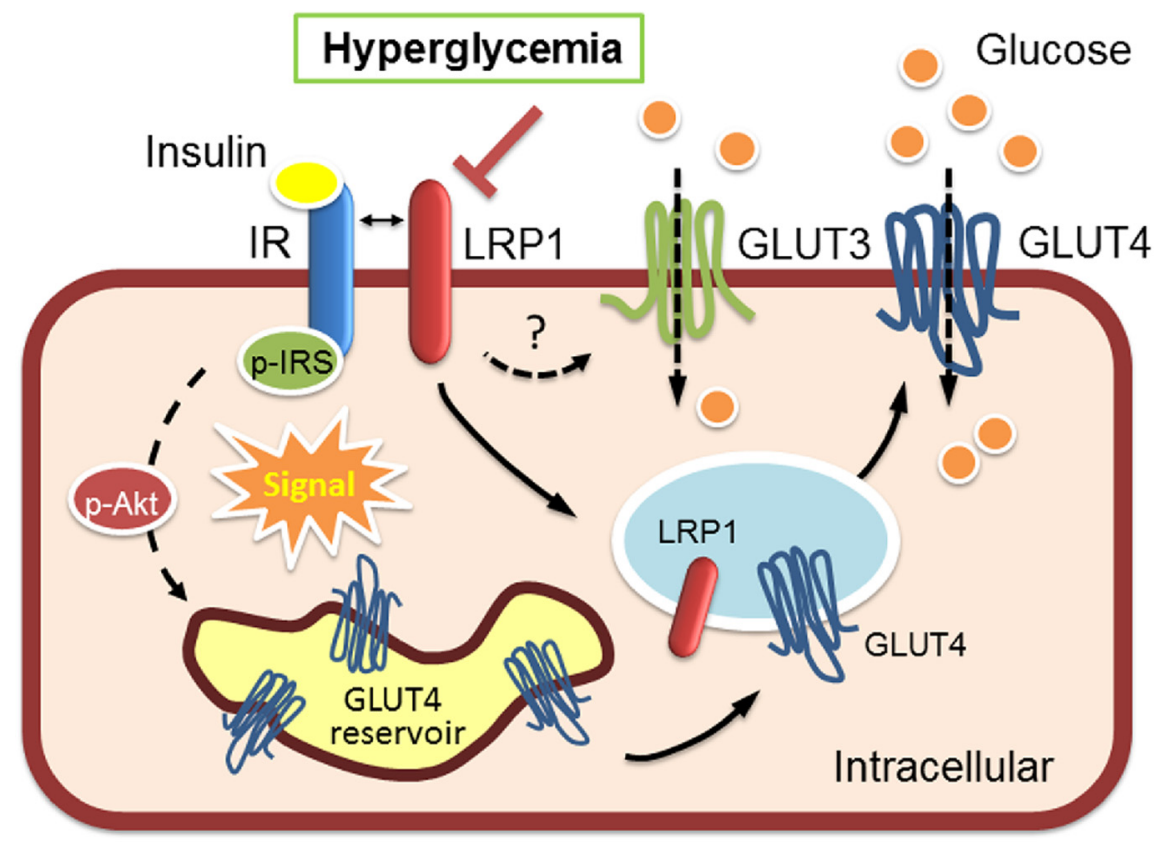

Figure 6. Model of neuronal LRP1 in the regulation of insulin signaling and glucose metabolism. LRP1 interacts with IR $\beta$ through which it regulates insulin signaling. LRP1 also affects glucose metabolism in neurons through modulation of glucose transporter expression and function. Hyperglycemia suppresses the levels of LRP1, which might further impair insulin signaling and glucose homeostasis in the brain.

between insulin signaling and synaptic plasticity. Indeed, intranasal administration of insulin has shown promising effects for patients with early $\mathrm{AD}$, thus leading to a nationwide Phase III insulin trial (Dhamoon et al., 2009; Craft et al., 2012). These findings suggest that aberrant insulin signaling may contribute to brain glucose hypometabolism and synaptic defects in $\mathrm{AD}$ pathogenesis.

In this study, we demonstrated that LRP1 interacting with IR $\beta$ and regulating the levels of GLUT might serve as a potential mechanism by which it modulates insulin signaling and glucose metabolism in the brain (Fig. 6). Previous studies have reported decreased IR levels (Steen et al., 2005) and reduced activation of the receptor tyrosine kinase domain in AD brains (Rivera et al., 2005; Talbot et al., 2012). In contrast, several other studies suggest that IR levels in the brain are similar between $\mathrm{AD}$ and control cases (Moloney et al., 2010; Ho et al., 2012; Talbot et al., 2012), whereas the subcellular distribution of IR is altered in neurons of AD brains (Moloney et al., 2010). LRP1 has been previously shown to interact with the NMDARs and controls their trafficking and degradation (Maier et al., 2013). Our recent findings also showed that knockdown of neuronal LRP1 decreases GluA1, a subunit of the $\alpha$-amino-3-hydroxy-5-methyl-4-isoxazolepropionicacid receptors (AMPARs), and PSD95 by accelerating their degradation (Gan et al., 2014). It is possible that LRP1 interacts with IR $\beta$ through which it regulates IR trafficking, stability, and downstream signaling in neurons. We found that deletion of Lrp1 in mouse forebrain neurons results in decreased $\operatorname{IR} \beta$ levels and impaired brain insulin signaling. Furthermore, using an in vivo microdialysis approach, we showed that brain glucose metabolism is compromised in LRP1 forebrain neuronal-specific knock-out mice. To our knowledge, this is the first report that monitors the changes of ISF glucose levels upon a glucose tolerance test in conscious and freely moving mice. The transport of glucose from blood across the blood-brain barrier is precisely regulated via facilitative glucose transporters because glu- cose is an essential substrate for cerebral oxidative metabolism (McEwen and Reagan, 2004). Whereas GLUT3 mainly mediates the internalization of glucose into neurons, GLUT4 is a major insulin-sensitive glucose transporter also expressed in neurons (McEwen and Reagan, 2004). GLUT3 and GLUT4 are critical to the regulation of neuronal metabolism and the generation of energy needed for cognitive function. Insulin stimulates translocation of GLUT4 to plasma membrane likely through recycling endosomes and/or the trans-Golgi network (Kandror and Pilch, 2011). In adipocytes, LRP1 was identified as a major component of GLUT4-positive vesicles, which interacts with the lumenal domains of GLUT4 (Jedrychowski et al., 2010). We found that LRP1 deficiency reduced both GLUT3 and GLUT4 levels in neuronal cells and mouse brains. Thus, our results demonstrate that LRP1 plays an important role in the regulation of brain glucose homeostasis by controlling glucose transporter levels as well as insulin signaling (Fig. 6).

In the brain of $\mathrm{AD}$ patients, FDG-PET imaging shows a decrease in cerebral glucose uptake compared with normal individuals (Jagust et al., 2007; Foster et al., 2008). These changes can be detected in normal controls and in MCI patients, who subsequently develop AD several years before the first symptoms of the disease (de Leon et al., 2001; Mosconi et al., 2008). Thus, the decreased cerebral glucose metabolism due to LRP1 dysfunction may contribute to the neuropathological changes associated with AD. Neuronal LRP1 not only modulates brain glucose homeostasis but also plays a critical role in brain lipid metabolism as an apoE receptor (Bu, 2009). ApoE-mediated lipid metabolism in neurons is important for synaptic functions in learning and memory (Liu et al., 2013). Abnormal lipid metabolism and APOE4 status have been strongly related to the pathogenesis of AD (Liu et al., 2013; Poirier et al., 2014). Interestingly, several studies suggest that diabetic patients carrying APOE4 allele have a greater risk for AD (Peila et al., 2002; Irie et al., 2008). A recent study also showed that long-acting insulin detemir improves cognition for patients with MCI or AD, and such effect was moderated by APOE genotype status (Claxton et al., 2015). Whether LRP1 plays a critical role in maintaining both lipid and glucose homeostasis in an apoE isoform-dependent manner in the brain deserves further investigation.

The STZ-induced diabetic animal model is characterized by high serum glucose resulting from disrupted islet $\beta$-cells. We also found that this diabetic mouse model exhibits an increased ISF glucose level and glucose intolerance in the brain. Furthermore, the expression of LRP1 in the brain was significantly reduced in STZ-induced diabetic mice, which is consistent with a previous finding that LRP1 expression in brain microvessels is reduced in diabetic model mice (Hong et al., 2009). Thus, decreasing LRP1 levels under diabetic conditions may reduce brain glucose utilization. In AD patients, brain LRP1 level is significantly decreased and inversely correlates with the age of onset (Kang et al., 2000). Our results also showed that insulin insufficiency may disturb LRP1 function by affecting its cellular distribution. Although further studies are needed, compromised glucose metabolism and 
insulin signaling in $\mathrm{AD}$ brain may be attributed to decreased LRP1 levels and dysfunction. It is possible that hyperglycemia downregulates LRP1 expression, thus initiating a vicious cycle in which insulin resistance and impaired glucose metabolism in $\mathrm{AD}$ brains synergistically promote AD pathogenesis (Fig. 6).

In conclusion, our results demonstrate that neuronal LRP1 plays a crucial role in regulating insulin signaling and glucose metabolism in the brain. LRP1 deficiency in neurons and insulin resistance synergistically contribute to impaired glucose metabolism and synaptic dysfunction, which are likely the very early abnormalities that precede or accompany the initial stages of cognitive impairment. Our studies provide novel insights into the pathogenic mechanisms that link LRP1, insulin resistance, and impaired glucose metabolism to $\mathrm{AD}$, and suggest that targeting LRP1-regulated insulin signaling might be effective in ameliorating the clinical symptoms in the early stages of AD.

\section{References}

Ardestani A, Paroni F, Azizi Z, Kaur S, Khobragade V, Yuan T, Frogne T, Tao W, Oberholzer J, Pattou F, Kerr Conte J, Maedler K (2014) MST1 is a key regulator of beta cell apoptosis and dysfunction in diabetes. Nat Med 20:385-397. CrossRef Medline

Baker LD, Cross DJ, Minoshima S, Belongia D, Watson GS, Craft S (2011) Insulin resistance and Alzheimer-like reductions in regional cerebral glucose metabolism for cognitively normal adults with prediabetes or early type 2 diabetes. Arch Neurol 68:51-57. CrossRef Medline

Biessels GJ, Staekenborg S, Brunner E, Brayne C, Scheltens P (2006) Risk of dementia in diabetes mellitus: a systematic review. Lancet Neurol 5:64-74. CrossRef Medline

Blomstrand F, Giaume C (2006) Kinetics of endothelin-induced inhibition and glucose permeability of astrocyte gap junctions. J Neurosci Res 83: 996-1003. CrossRef Medline

Brands AM, Biessels GJ, de Haan EH, Kappelle LJ, Kessels RP (2005) The effects of type 1 diabetes on cognitive performance: a meta-analysis. Diabetes Care 28:726-735. CrossRef Medline

Bu G (2009) Apolipoprotein E and its receptors in Alzheimer's disease: pathways, pathogenesis and therapy. Nat Rev Neurosci 10:333-344. CrossRef Medline

Bu G, Geuze HJ, Strous GJ, Schwartz AL (1995) 39 kDa receptor-associated protein is an ER resident protein and molecular chaperone for LDL receptor-related protein. EMBO J 14:2269-2280. Medline

Claxton A, Baker LD, Hanson A, Trittschuh EH, Cholerton B, Morgan A, Callaghan M, Arbuckle M, Behl C, Craft S (2015) Long-acting intranasal insulin detemir improves cognition for adults with mild cognitive impairment or early-stage Alzheimer's disease dementia. J Alzheimers Dis 44: 897-906. CrossRef Medline

Cohen AD, Klunk WE (2014) Early detection of Alzheimer's disease using $\mathrm{PiB}$ and FDG PET. Neurobiol Dis 72:117-122. CrossRef Medline

Craft S, Baker LD, Montine TJ, Minoshima S, Watson GS, Claxton A, Arbuckle M, Callaghan M, Tsai E, Plymate SR, Green PS, Leverenz J, Cross D, Gerton B (2012) Intranasal insulin therapy for Alzheimer disease and amnestic mild cognitive impairment: a pilot clinical trial. Arch Neurol 69:29-38. CrossRef Medline

de la Monte SM, Wands JR (2008) Alzheimer's disease is type 3 diabetesevidence reviewed. J Diabetes Sci Technol 2:1101-1113. CrossRef Medline

de Leon MJ, Convit A, Wolf OT, Tarshish CY, DeSanti S, Rusinek H, Tsui W, Kandil E, Scherer AJ, Roche A, Imossi A, Thorn E, Bobinski M, Caraos C, Lesbre P, Schlyer D, Poirier J, Reisberg B, Fowler J (2001) Prediction of cognitive decline in normal elderly subjects with 2-[(18)F]fluoro-2deoxy-D-glucose/poitron-emission tomography (FDG/PET). Proc Natl Acad Sci U S A 98:10966-10971. CrossRef Medline

Dhamoon MS, Noble JM, Craft S (2009) Intranasal insulin improves cognition and modulates beta-amyloid in early AD. Neurology 72:292-293; author reply 293-294. CrossRef Medline

Foster NL, Wang AY, Tasdizen T, Fletcher PT, Hoffman JM, Koeppe RA (2008) Realizing the potential of positron emission tomography with 18F-fluorodeoxyglucose to improve the treatment of Alzheimer's disease. Alzheimers Dement 4 [Suppl 1]:S29-S36.

Gan M, Jiang P, McLean P, Kanekiyo T, Bu G (2014) Low-density lipopro- tein receptor-related protein 1 (LRP1) regulates the stability and function of GluA1 alpha-amino-3-hydroxy-5-methyl-4-isoxazole propionic acid (AMPA) receptor in neurons. PLoS One 9:e113237. CrossRef Medline

Gerozissis K (2003) Brain insulin: regulation, mechanisms of action and functions. Cell Mol Neurobiol 23:1-25. CrossRef Medline

Herz J, Strickland DK (2001) LRP: a multifunctional scavenger and signaling receptor. J Clin Invest 108:779-784. CrossRef Medline

Ho L, Yemul S, Knable L, Katsel P, Zhao R, Haroutunian V, Pasinetti GM (2012) Insulin receptor expression and activity in the brains of nondiabetic sporadic Alzheimer's disease cases. Int J Alzheimers Dis 2012: 321280. CrossRef Medline

Hong H, Liu LP, Liao JM, Wang TS, Ye FY, Wu J, Wang YY, Wang Y, Li YQ, Long Y, Xia YZ (2009) Downregulation of LRP1 [correction of LPR1] at the blood-brain barrier in streptozotocin-induced diabetic mice. Neuropharmacology 56:1054-1059. CrossRef Medline

Hoyer S (2004) Glucose metabolism and insulin receptor signal transduction in Alzheimer disease. Eur J Pharmacol 490:115-125. CrossRef Medline

Irie F, Fitzpatrick AL, Lopez OL, Kuller LH, Peila R, Newman AB, Launer LJ (2008) Enhanced risk for Alzheimer disease in persons with type 2 diabetes and APOE epsilon4: the Cardiovascular Health Study Cognition Study. Arch Neurol 65:89-93. CrossRef Medline

Jagust W, Reed B, Mungas D, Ellis W, Decarli C (2007) What does fluorodeoxyglucose PET imaging add to a clinical diagnosis of dementia? Neurology 69:871-877. CrossRef Medline

Janson J, Laedtke T, Parisi JE, O’Brien P, Petersen RC, Butler PC (2004) Increased risk of type 2 diabetes in Alzheimer disease. Diabetes 53:474481. CrossRef Medline

Jedrychowski MP, Gartner CA, Gygi SP, Zhou L, Herz J, Kandror KV, Pilch PF (2010) Proteomic analysis of GLUT4 storage vesicles reveals LRP1 to be an important vesicle component and target of insulin signaling. J Biol Chem 285:104-114. CrossRef Medline

Kahn SE, Hull RL, Utzschneider KM (2006) Mechanisms linking obesity to insulin resistance and type 2 diabetes. Nature 444:840-846. CrossRef Medline

Kandror KV, Pilch PF (2011) The sugar is sIRVed: sorting Glut4 and its fellow travelers. Traffic 12:665-671. CrossRef Medline

Kanekiyo T, Bu G (2014) The low-density lipoprotein receptor-related protein 1 and amyloid-beta clearance in Alzheimer's disease. Front Aging Neurosci 6:93. CrossRef Medline

Kanekiyo T, Cirrito JR, Liu CC, Shinohara M, Li J, Schuler DR, Shinohara M,Holtzman DM, Bu G (2013) Neuronal clearance of amyloid-beta by endocytic receptor LRP1. J Neurosci 33:19276-19283. CrossRef Medline

Kang DE, Pietrzik CU, Baum L, Chevallier N, Merriam DE, Kounnas MZ, Wagner SL, Troncoso JC, Kawas CH, Katzman R, Koo EH (2000) Modulation of amyloid beta-protein clearance and Alzheimer's disease susceptibility by the LDL receptor-related protein pathway. J Clin Invest 106: 1159-1166. CrossRef Medline

Kleinridders A, Ferris HA, Cai W, Kahn CR (2014) Insulin action in brain regulates systemic metabolism and brain function. Diabetes 63:22322243. CrossRef Medline

Ko KW, Avramoglu RK, McLeod RS, Vukmirica J, Yao Z (2001) The insulin-stimulated cell surface presentation of low density lipoprotein receptor-related protein in 3T3-L1 adipocytes is sensitive to phosphatidylinositide 3-kinase inhibition. Biochemistry 40:752-759. CrossRef Medline

Lillis AP, Van Duyn LB, Murphy-Ullrich JE, Strickland DK (2008) LDL receptor-related protein 1: unique tissue-specific functions revealed by selective gene knockout studies. Physiol Rev 88:887-918. CrossRef Medline

Liposits Z, Merchenthaler I, Wetsel WC, Reid JJ, Mellon PL, Weiner RI, Negro-Vilar A (1991) Morphological characterization of immortalized hypothalamic neurons synthesizing luteinizing hormone-releasing hormone. Endocrinology 129:1575-1583. CrossRef Medline

Liu CC, Kanekiyo T, Xu H, Bu G (2013) Apolipoprotein E and Alzheimer disease: risk, mechanisms and therapy. Nat Rev Neurol 9:106-118. CrossRef Medline

Liu Q, Zerbinatti CV, Zhang J, Hoe HS, Wang B, Cole SL, Herz J, Muglia L, Bu G (2007) Amyloid precursor protein regulates brain apolipoprotein $\mathrm{E}$ and cholesterol metabolism through lipoprotein receptor LRP1. Neuron 56:66-78. CrossRef Medline

Liu Q, Trotter J, Zhang J, Peters MM, Cheng H, Bao J, Han X, Weeber EJ, Bu G (2010) Neuronal LRP1 knockout in adult mice leads to impaired 
brain lipid metabolism and progressive, age-dependent synapse loss and neurodegeneration. J Neurosci 30:17068-17078. CrossRef Medline

Maier W, Bednorz M, Meister S, Roebroek A, Weggen S, Schmitt U, Pietrzik CU (2013) LRP1 is critical for the surface distribution and internalization of the NR2B NMDA receptor subtype. Mol Neurodegener 8:25. CrossRef Medline

McEwen BS, Reagan LP (2004) Glucose transporter expression in the central nervous system: relationship to synaptic function. Eur J Pharmacol 490:13-24. CrossRef Medline

Minoshima S (2003) Imaging Alzheimer's disease: clinical applications. Neuroimaging Clin North Am 13:769-780. CrossRef Medline

Moloney AM, Griffin RJ, Timmons S, O'Connor R, Ravid R, O’Neill C (2010) Defects in IGF-1 receptor, insulin receptor and IRS-1/2 in Alzheimer's disease indicate possible resistance to IGF-1 and insulin signalling. Neurobiol Aging 31:224-243. CrossRef Medline

Mosconi L, De Santi S, Li J, Tsui WH, Li Y, Boppana M, Laska E, Rusinek H, de Leon MJ (2008) Hippocampal hypometabolism predicts cognitive decline from normal aging. Neurobiol Aging 29:676-692. CrossRef Medline

Mosconi L, Mistur R, Switalski R, Tsui WH, Glodzik L, Li Y, Pirraglia E, De Santi S, Reisberg B, Wisniewski T, de Leon MJ (2009) FDG-PET changes in brain glucose metabolism from normal cognition to pathologically verified Alzheimer's disease. Eur J Nucl Med Mol Imaging 36:811-822. CrossRef Medline

Mosconi L, Berti V, Glodzik L, Pupi A, De Santi S, de Leon MJ (2010) Preclinical detection of Alzheimer's disease using FDG-PET, with or without amyloid imaging. J Alzheimers Dis 20:843-854. CrossRef Medline

Park CR (2001) Cognitive effects of insulin in the central nervous system. Neurosci Biobehav 25:311-323. CrossRef Medline

Peila R, Rodriguez BL, Launer LJ (2002) Type 2 diabetes, APOE gene, and the risk for dementia and related pathologies: the Honolulu-Asia Aging Study. Diabetes 51:1256-1262. CrossRef Medline

Poirier J, Miron J, Picard C, Gormley P, Theroux L, Breitner J, Dea D (2014) Apolipoprotein E and lipid homeostasis in the etiology and treatment of sporadic Alzheimer's disease. Neurobiol Aging 35 [Suppl 2]:S3-S10.

Porras OH, Loaiza A, Barros LF (2004) Glutamate mediates acute glucose transport inhibition in hippocampal neurons. J Neurosci 24:9669-9673. CrossRef Medline

Rivera EJ, Goldin A, Fulmer N, Tavares R, Wands JR, de la Monte SM (2005) Insulin and insulin-like growth factor expression and function deteriorate with progression of Alzheimer's disease: link to brain reductions in acetylcholine. J Alzheimers Dis 8:247-268. Medline

Rohlmann A, Gotthardt M, Hammer RE, Herz J (1998) Inducible inactivation of hepatic LRP gene by cre-mediated recombination confirms role of LRP in clearance of chylomicron remnants. J Clin Invest 101:689-695. CrossRef Medline

Simpson IA, Chundu KR, Davies-Hill T, Honer WG, Davies P (1994) Decreased concentrations of GLUT1 and GLUT3 glucose transporters in the brains of patients with Alzheimer's disease. Ann Neurol 35:546-551. CrossRef Medline
Sims-Robinson C, Kim B, Rosko A, Feldman EL (2010) How does diabetes accelerate Alzheimer disease pathology? Nat Rev Neurol 6:551-559. CrossRef Medline

Skeberdis VA, Lan J, Zheng X, Zukin RS, Bennett MV (2001) Insulin promotes rapid delivery of N-methyl-D-aspartate receptors to the cell surface by exocytosis. Proc Natl Acad Sci U S A 98:3561-3566. CrossRef Medline

Steen E, Terry BM, Rivera EJ, Cannon JL, Neely TR, Tavares R, Xu XJ, Wands JR, de la Monte SM (2005) Impaired insulin and insulin-like growth factor expression and signaling mechanisms in Alzheimer's disease: is this type 3 diabetes? J Alzheimers Dis 7:63-80. Medline

Stewart SA, Dykxhoorn DM, Palliser D, Mizuno H, Yu EY, An DS, Sabatini DM, Chen IS, Hahn WC, Sharp PA, Weinberg RA, Novina CD (2003) Lentivirus-delivered stable gene silencing by RNAi in primary cells. RNA 9:493-501. CrossRef Medline

Stolk RP, Breteler MM, Ott A, Pols HA, Lamberts SW, Grobbee DE, Hofman A (1997) Insulin and cognitive function in an elderly population: the Rotterdam Study. Diabetes Care 20:792-795. CrossRef Medline

Talbot K, Wang HY, Kazi H, Han LY, Bakshi KP, Stucky A, Fuino RL, Kawaguchi KR, Samoyedny AJ, Wilson RS, Arvanitakis Z, Schneider JA, Wolf BA, Bennett DA, Trojanowski JQ, Arnold SE (2012) Demonstrated brain insulin resistance in Alzheimer's disease patients is associated with IGF-1 resistance, IRS-1 dysregulation, and cognitive decline. J Clin Invest 122:1316-1338. CrossRef Medline

Tamaki C, Ohtsuki S, Terasaki T (2007) Insulin facilitates the hepatic clearance of plasma amyloid beta-peptide (140) by intracellular translocation of low-density lipoprotein receptor-related protein 1 (LRP-1) to the plasma membrane in hepatocytes. Mol Pharmacol 72:850-855. CrossRef Medline

Thies W, Bleiler L (2013) 2013 Alzheimer's disease facts and figures. Alzheimers Dement 9:208-245. CrossRef Medline

Tsien JZ, Chen DF, Gerber D, Tom C, Mercer EH, Anderson DJ, Mayford M, Kandel ER, Tonegawa S (1996) Subregion- and cell type-restricted gene knockout in mouse brain. Cell 87:1317-1326. CrossRef Medline

Yamada K, Nakata M, Horimoto N, Saito M, Matsuoka H, Inagaki N (2000) Measurement of glucose uptake and intracellular calcium concentration in single, living pancreatic beta-cells. J Biol Chem 275:22278-22283. CrossRef Medline

Yamada K, Saito M, Matsuoka H, Inagaki N (2007) A real-time method of imaging glucose uptake in single, living mammalian cells. Nat Protoc 2:753-762. CrossRef Medline

Zhao W, Chen H, Xu H, Moore E, Meiri N, Quon MJ, Alkon DL (1999) Brain insulin receptors and spatial memory: correlated changes in gene expression, tyrosine phosphorylation, and signaling molecules in the hippocampus of water maze trained rats. J Biol Chem 274:34893-34902. CrossRef Medline

Zhou J, Martin RJ, Tulley RT, Raggio AM, McCutcheon KL, Shen L, Danna SC, Tripathy S, Hegsted M, Keenan MJ (2008) Dietary resistant starch upregulates total GLP-1 and PYY in a sustained day-long manner through fermentation in rodents. Am J Physiol Endocrinol Metab 295:E1160 E1166. CrossRef Medline 